\title{
Conciliar Christology and the Problem of Incompatible Predications
}

\section{TIMOTHY PAWL}

Associate Professor of Philosophy, University of St. Thomas (MN), USA

timpawl@stthomas.edu

\begin{abstract}
In this article I canvas the options available to a proponent of the traditional doctrine of the incarnation against a charge of incoherence. In particular, I consider the charge of incoherence due to incompatible predications both being true of the same one person, the God-man Jesus Christ. For instance, one might think that anything divine has to have certain attributes - perhaps omnipotence, or impassibility. But, the charge continues, nothing human can be omnipotent or impassible. And so nothing can be divine and human. So Christ is not both God and man, contrary to the traditional doctrine of the incarnation. To do so, first, in Section II, I will present the problem as a deductively valid argument. I then, in that section, go on to show that the proponent of traditional Christology should grant all but one premise of the argument. In the remaining sections I will canvas possible solutions to the problem. In Section III I discuss three ways to deny Premise 3 of the forthcoming argument. These ways include a Kenotic response, qua-modification (in four versions), and finally a response that accepts the compatibility of the allegedly incompatible predicates.
\end{abstract}

Keywords: Conciliar Christology; Kenotic Christology; Qua-clauses; Incarnation; Incompatible Predicates. 


\section{Introduction}

In this article I canvas the options available to a proponent of the traditional doctrine of the incarnation against a charge of incoherence. In particular, I consider the charge of incoherence due to incompatible predications both being true of the same one person, the God-man Jesus Christ. ${ }^{1}$ For instance, one might think that anything divine has to have certain attributes - perhaps omnipotence, or impassibility. But, the charge continues, nothing human can be omnipotent or impassible. And so nothing can be divine and human. So Christ is not both God and man, contrary to the traditional doctrine of the incarnation.

To do so, first, in Section II, I will present the problem as a deductively valid argument. I then, in that section, go on to show that the proponent of traditional Christology should grant all but one premise of the argument. In the remaining sections I will canvas possible solutions to the problem. In Section III I discuss three ways to deny Premise 3 of the forthcoming argument. These ways include a Kenotic response, qua-modification (in four versions), and finally a response that accepts the compatibility of the allegedly incompatible predicates. ${ }^{2}$

Consider the earliest seven Ecumenical Councils-the Councils held as binding by both Catholic and Orthodox Christians: the First Council of Nicaea, 325; the First Council of Constantinople, 381; the Council of Ephesus, 431; the Council of Chalcedon, 451 ; the Second Council of Constantinople, 553; the Third Council of Constantinople, 680-681; the Second Council of Nicaea, $787 .{ }^{3}$ Call the conjunction of the teachings from these

1 This article summarizes the work I do in much greater detail in Chapters 4-7 of In Defense of Conciliar Christology: A Philosophical Essay (Pawl 2016b).

2 I develop this third way in far more detail in my "A Solution to the Fundamental Philosophical Problem of Christology” (Pawl 2014a).

3 Very many Orthodox Christians would consider these, not just the earliest, but the only seven Ecumenical Councils. Very many Protestant Christians consider some proper subset of these councils as binding, in some sense. Catholics consider these a subset of the Ecumenical Councils, which continue on through the Second Vatican Council. 
Councils concerning the incarnation Conciliar Christology. ${ }^{4}$ The Church fathers at the Third Council of Constantinople, in their Exposition of the faith, summarize most of the important points of Conciliar Christology in the following passage:

Following the five holy and universal synods and the holy and accepted fathers, and defining in unison, it [the $3^{\text {rd }}$ Council of Constantinople] professes our lord Jesus Christ our true God, one of the holy Trinity, which is of one same being and is the source of life, to be perfect in divinity and perfect in humanity, the same truly God and truly man, of a rational soul and a body (Tanner 1990, 127-128).

I will not argue for the truth of Conciliar Christology in this article. Rather, I will assume it to be true, and consider some responses one might give to a difficult objection it faces.

\section{The Problem}

Richard Cross $(2011,453)$ states the main philosophical difficulty of Christology as follows:

[T] he fundamental philosophical problem specific to the doctrine is this: how is it that one and the same thing could be both divine (and thus, on the face of it, necessary, and necessarily omniscient, omnipotent, eternal, immutable, impassible, and impeccable) and human (and thus, on the face of it, have the complements of all these properties)?

Call this problem "the Fundamental Problem," or just "the Problem" for short. Prior to considering the traditional doctrine of the incarnation, one is inclined to think that there are some predicates that must be true of

4 What counts as a "teaching" of the councils? I refer to the definitions and expositions of faith, creeds, canons, and anathemas of the councils. If such definitions accept other documents (e.g., as Chalcedon's Definition of the Faith accepts both Cyril's letters to Nestorius and to John of Antioch, as well as Leo's Tome), I will include those other documents as part of what I take to be the teaching of the councils. 
anything divine, but cannot be true of anything human. For example, anything worthy of being called "divine" needs to be necessarily existent, or necessarily omnipotent; but nothing could be a human and be necessarily existent or omnipotent. Christ, though, is both truly divine and truly human on Conciliar Christology. But it is impossible for a predicate and its complement both to be apt of the same thing at the same time in the same way. Thus, we have arrived at a contradiction.

One can put the argument in a more explicit form. Consider "passible" and "impassible" as a test case of potentially incompatible predicates. Readers uncomfortable with "impassible" as a predicate of the divine can supply another predicate from Cross's list as a test case.

1. Anything divine is impassible

(assume)

2. Anything human is passible (assume)

3. Nothing can be both passible and impassible

(assume)

4. Christ is divine and human (Conciliar Christology)

5. Christ is both passible and impassible (From 1, 2, 4)

6. Contradiction! (From 3, 5)

Premises 1-4 entail a contradiction. So at least one of them must be false. But which? What options are available to the defender of Conciliar Christology?

Denying Premise 4 is not a viable strategy for the defender of Conciliar Christology. For, as we have seen above, the texts clearly claim that Christ was both divine and human. In addition, the earliest creeds claim that Christ was both "true God from true God" and "became man" (Tanner 1990, 5). What remains for the Conciliar Christologist, then, is denying one of Premises 1-3.

After Premise 4, Premise 2 is the next least plausible candidate for denial. For the Creed of Nicaea says "for us humans and for our salvation he came down and became incarnate, became human, suffered [passus est in the Latin translation] and rose up on the third day..." (Tanner 1990, 5). Moreover, Leo says in his Tome, which was ratified at the Council of Chalcedon: 
To pay off the debt of our state, invulnerable nature was united to a nature that could suffer; so that in a way that corresponded to the remedies we needed, one and the same mediator between God and humanity, the man Christ Jesus, could both on the one hand die and on the other be incapable of death [et mori posset ex uno et mori non posset ex altero] (Tanner 1990, 78).

The claim that Christ was causally affectable and in fact causally affected during his life and death is essential to Christianity. But from this it follows that Christ was passible. It is true that this support for Premise 2 does not show that all humans are passible, which is what Premise 2 states. Nevertheless, the only contentious case could be the case of Christ - no one doubts that all mere humans are causally affectable. The support I offer here with respect to the Christ case, in conjunction with the ample evidence we have for the claim that all mere humans are able to be causally affected, is sufficient to motivate the acceptance of Premise 2, were anyone in fact inclined to deny it.

The remaining two premises one might deny are Premise 1, a theological premise, and Premise 3, a metaphysical or semantic premise. The denial of Premise 1 is commonplace in contemporary theological discussions. For instance, Richard Cross (2011, 464, 470-471) denies impassibility in light of the Problem addressed in this article. I do not think that this response is available to the proponent of Conciliar Christology. For the collected fathers at the Council of Ephesus unanimously affirmed the impassibility of the Christ. To cite just one passage, Cyril says, writing on their communal behalf in a letter included in the Conciliar documents, "We all confess that the Word of God is impassible, though in his all-wise economy of the mystery he is seen to attribute to himself the sufferings undergone by his own flesh" (Tanner 1990, 72-73). Moreover, the gathered fathers at Chalcedon claimed in union that the great council "expels from the assembly of the priests those who dare to say that the divinity of the Only-begotten is passible" (Tanner 1990, 85-86). Because of these texts, and others like them, I think that the proponent of Conciliar Christology ought not to deny Premise 1. 
Before discussing Premise 3, note that the intermediate step, 5, follows from the three Premises already discussed: 1,2 , and 4 . And so we have seen that Conciliar Christology is committed to Step 5. However, even if 1, 2, or 4 were false, or my justification of one of them were insufficient, there would still be independent reason why the defender of Conciliar Christology must accept 5. The seventh Ecumenical Council, Second Nicaea

professed the one and same Christ as both invisible and visible lord, incomprehensible and comprehensible, unlimited and limited, incapable and capable of suffering [impassibilem etiam et passibilem], inexpressible and expressible in writing” (Tanner 1990, 162). ${ }^{5}$

This quotation does not provide evidence that either Premise 1 or Premise 2 is true. For all this quotation says, both premises could be false. Nevertheless, it does provide evidence that the proponent of Conciliar Christology ought to accept Step 5 of the argument. And it is that fifth step, together with Premise 3, that yields the contradiction at Line 6. I conclude, then, that there is strong evidence for the proponent of Conciliar Christology to accept steps 1, 2, 4, and 5 of this argument. The committed proponent of Conciliar Christology, then, ought to deny Premise 3.

\section{Three Ways to Deny Premise 3}

The problem with denying Premise 3 is that it seems intuitively true. How could one thing be passible and impassible, or visible and invisible, to use another example from the previous quotation? If someone were visible and invisible, could you see him? If he were impassible and passible, and you punched him, could you hurt him? In what follows I will discuss multiple ways of rejecting or revising Premise 3 so as to avoid the Problem. The first way will be to modify Premise 3 so that it means that nothing can be impassible and passible at the same time, then to claim that Conciliar

5 To see the text from Second Nicaea, see (Lamberz 2008, 3.1:254-259). For a similar text of apparently contradictory conjunctions from the Third Council of Constantinople (680-681), see (Riedinger 1990, 2:454). 
Christology doesn't claim that Christ was both at the same time. The second way will be to modify Premise 3 so that it means that nothing can be impassible and passible in the same way, and then to use qua-clauses - "qua his human nature" and "qua his divine nature" - to claim that Premise 5 does not require Christ to be both passible and impassible in the same way. The third way will be to reject Premise 3 flat-footedly. When understood correctly, some one thing can be both passible and impassible at the same time, in the same way, under very specific conditions. Christ, on this view, fulfilled those conditions.

Consider the first way of critiquing Premise 3 listed above. One might claim that nothing can be both passible and impassible at the same time, and that this is what Premise 3 is meant to convey. Then, one could accept that Christ was both passible and impassible, but deny that he was ever both at the same time. One sees this approach taken by some Kenotic thinkers, who claim that the Word's self-emptying in the incarnation requires his jettisoning some of his divine attributes. ${ }^{6}$ While he was impassible prior to the incarnation, he ceases to be when he becomes incarnate. Likewise for other attributes - while he was omnipotent, or immutable, or eternal, or invisible, etc., when not incarnate, he ceased being all of these while incarnate.

I think the Conciliar Christologist does well to avoid this view. ${ }^{7}$ For it requires that the Word change in ways the councils denied. For instance, the proponents of Kenoticism speak of Christ ceasing to be omnipotent or omnipresent. ${ }^{8}$ However, the Conciliar texts support the view that he retained both those attributes. For instance, a text from Ephesus says:

For although visible as a child and in swaddling cloths, even while he was in the bosom of the virgin that bore him, as God he filled the whole of creation and was fellow ruler with him who begot him (Tanner 1990, 51).

6 For expositions or in depth discussion of Kenotic Christology, see Davis (2011), Evans (2006), Forrest (2009) Morris (1987, 89-102), Senor (2011), Sturch (1991, 252-260), and Weinandy (1985, chap. 4). For the history of Kenoticism, see Thomas Thompson (2006).

7 I discuss these reasons in much greater depth in Pawl (2016b, chap. 5, section V.b.).

8 See, for instance, C. Stephen Evans $(2006,7)$ and Thomas Senor $(2011,110)$. 
And Leo writes:

For that self-emptying whereby the invisible rendered himself visible, and the Creator and Lord of all things chose to join the ranks of mortals, spelled no failure of power: it was an act of merciful favour (Tanner 1990, 78).

I take the first text to give evidence that the Word remained omnipresent in the incarnation, and the second to give evidence that he lost no power in the incarnation.

Moreover, historians of the councils and of the great thinkers who shaped their doctrine agree that the councils do not understand the Word to have given up these attributes. Leo Davis in his book, The First Seven Ecumenical Councils (325-787): Their History and Theology $(1990,175)$ writes of their view:

Though the Incarnation involved a self-emptying, this should be understood as a stooping down whereby the Word underwent no diminution of His omnipotence.

Gregory Dunn (2001) a scholar of Leo, writes that Leo thought "that Jesus could be both impassible and passible at the same time without there being any contradiction" $(2001,81)$. For these reasons, I read the councils as being inconsistent with the response to the argument under consideration here. If we are to retain Conciliar Christology and do so by denying or modifying Premise 3, we need to do it in another way.

The second way I mentioned to modify Premise 3 is to add in a modifier. The first modifier we considered was "at the same time." The modifier under consideration now is "in the same way" or "in the same sense." This modifier is most often presented in the Christological literature by means of a "qua" clause affixed to the modified proposition. Christ is impassible qua divine; he is passible qua human. Since he is passible and impassible in different ways, or in different senses, he is not both impassible and passible in the same sense. And so the affirmation of Step 5 is not in conflict with the correct understanding of Premise 3 - or, at least, this solution 
claims. Were the predicates meant in the same way of the same thing at the same time, then, on this solution, there would be a contradiction. But the conditions of the antecedent are not met, since the predicates are said in different ways.

There are multiple ways to understand these qua modifications. ${ }^{9}$ The modifier "qua human" in the predication "Christ is passible qua human" can be understood to modify the whole predication "Christ is passible." Or it could modify any of the three parts of that predication - the subject, "Christ”; the copula, "is"; or the predicate, "passible." We can present these four possibilities, as I have elsewhere, as follows:

$\begin{array}{lll}\text { Assertion (A): } & \text { Qua H, C is P } & \text { Qua D, C is I } \\ \text { Subject (S): } & \text { C-qua-H is P } & \text { C-qua-D is I } \\ \text { Predicate (P): } & \text { C is } P \text {-qua-H } & \text { C is I-qua-D } \\ \text { Copula (C): } & \text { C is-qua-H P } & \text { C is-qua-D I. }\end{array}$

In what follows I will consider these ways of understanding the qua modifier.

The first way of understanding the qua-clause is to read it as modifying the whole assertion. According to his human nature, Christ is passible. According to his divine nature, Christ is impassible. Here the qua functions explanatorily. It gives the reason or account why something is the case. It is because of his divine nature, and not because of his human nature, that he is impassible.

The main problem pointed out in the literature concerning the first way of reading “qua” is that it doesn't insulate against complementary predications being true of Christ. ${ }^{10}$ If the "qua" merely tells us in virtue of what it is that the thing is a certain way, then the thing's being that certain way follows. If "Christ qua human is passible" merely tells us that it is in virtue of being human that he is passible, then it follows that "Christ is passible." Likewise, it would follow from "Christ qua divine is impassible" that "Christ is impassible." But then the qua-clause doesn't give us any way

9 I discuss them at length in Pawl (2016a) and Pawl (2016b, chap. 6).

10 See, for instance, Adams (2009, 254-255), Bäck (1998, 84-87), Cross (2005, 193-195; 2011, 455-456), Morris (1987, 48-49), and Senor (2002, 229). 
to get these two predications true in difference senses, which is what we need to avoid the contradiction in the Problem. As such, the (A) reading is not the reading to employ in modifying our understanding of Premise 3.

Consider the second way to understand qua clauses - the qua modifies the subject. ${ }^{11}$ On such a view, the subject of the predication "Christ is impassible" is really Christ-qua-divine. Likewise, the subject of "Christ is passible" is really Christ-qua-human. And these are different subjects. For if it were one and the same subject being predicated by both "passible" and "impassible," then there would be no reprieve from contradiction. If it were really one and the same subject of both predications, then one thing would be both passible and impassible in the same sense. Recall that on this view, the one and only way one guarantees different senses is by the qua-modification of the subject. But if that qua-modification doesn't provide distinct subjects, then the same thing is predicated by both a predicate and an inconsistent predicate - in our test case, by both "passible" and "impassible." And so, for the (S) theory to work, there must be two subjects of predication, one that we can call "Christ-qua-human," the other that we can call "Christ-qua-divine." One should notice that, on this view, it will not work to have some third subject of predication that both "passible" and "impassible" are apt of. For that's the very problem we are trying to avoid with the qua-clauses. It is this affirmation of two distinct subjects of predication, and the concomitant denial of any third thing that shares the predicates, that makes the $(S)$ theory unworkable for the Conciliar Christologist.

Conciliar Christology requires that there be one thing to which the divine and human predicates apply in the incarnation - they both must apply to the person of Jesus Christ. Recall the quotation above from Leo, which states that

one and the same mediator between God and humanity, the man Christ Jesus, could both on the one hand die and on the other be incapable of death. (Tanner 1990, 78)

11 For discussions of this view, see Adams (2009, 255-256), Cross (2005, 195-199; 2011, 456), Flint (2011), Senor (2002, 229-230), and Stump (2004; 2005, chap. 14). 
Also, Cyril says in his third letter to Nestorius, "in thinking rightly, we refer both the human and divine expressions to the same person" (Tanner 1990, 55). ${ }^{12}$ So Conciliar Christology requires that there be one shared subject of the human and divine predicates. As such, it is inconsistent with Conciliar Christology to insulate the predications to different subjects according to the different natures and not allow them all to be true of the one person.

Consider the third way to read the qua-clauses - the way of modifying the predicate. ${ }^{13}$ On this view, the predicate in our example predication, "Christ is impassible" is really impassible-qua-divine. Likewise, the predicate in "Christ is passible" is really passible-qua-human. On this view, unlike the (S) view, it is one and the same thing - the person Jesus Christ - being predicated by both predicates. However, the predicates are not incompatible, according to the $(\mathrm{P})$ theorist. The $(\mathrm{P})$ theorist will maintain that while "passible" and "impassible" are incompatible, "impassible-qua-divine" and "passible-qua-human" are not. At least, she should say this. If she were to deny the incompatibility of "passible" and "impassible," she wouldn't need to posit qua-modified predicates to get around the inconsistency. The main motivation for saying that the predicates really are qua-modified rather than not is precisely because such modification allegedly protects against the contradiction that would arise, were the predicates not so modified.

At this point, one begins to wonder which predicates get the appended qua modifier. ${ }^{14}$ Is every predicate apt of Christ qua-modified? Are only some? If some, which? It would be a shame if the answer were "just the ones that cause problems," since that is an ad hoc standard. ${ }^{15}$

12 See also Cyril's third letter to Nestorius (55-56), the Exposition of faith from $3^{\text {rd }}$ Constantinople (129).

13 For some discussion of this understanding of qua-clauses in relation to Christology, see Adams (2009, 253-260), Bäck (1998), Cross (2005, 204-205; 2011, 457), and Senor (2002, 230-233).

14 For more objections to the (P) theory than I can discuss here, see (Pawl 2016b, Chapter 6, Sections V.a and V.b.)

15 Allan Bäck $(1997,347)$ makes this point against Scotus' (P) understanding of qua-clauses. 
Senor (2002, 230-232) challenges the (P) view by claiming that even if Christ is passible-qua-human and impassible-qua-God, there is still the further question of whether he is passible simpliciter or impassible simpliciter. Senor reasons that, for any property, a thing will either have it or have its complement. One might say similarly, for any predicate, a thing will either be aptly described by it or by its complement. And so even if the $(\mathrm{P})$ theorist is right that Christ is passible-qua-human and impassible-qua-God, the $(\mathrm{P})$ theorist still needs to give an answer to the question of whether Christ is passible simpliciter or impassible simpliciter.

If the $(\mathrm{P})$ theorist indexes all predicates to some nature or other, then she can avoid this objection. For then there is no predicate "passible (simpliciter)." Rather, all instances of "passible" as predicates are tacitly qualified by a nature. So she would deny Senor's claim that there is such a property or predicate as just plain passibility. Thus, she can avoid Senor's attempt to claim that there still must be a fact of the matter about whether Christ is passible simpliciter or not. There is no such thing, on her view, as the predicate "passible" simpliciter.

Indexing all predicates to a nature resolves the ad hoc worries, and it provides an answer to Senor's objection, but it also raises problems. If all the predicates are indexed to a nature, then the predicates apt of us are indexed to our nature, too. For instance, an apt predicate of Christ is "warm-blooded." But he wasn't warm-blooded simpliciter, he was "warmblooded-qua-human." Again, on this view, there is no "warm-blooded simpliciter." We, likewise, then, are "warm-blooded-qua-human.”

This causes problems for other things we think are true. For instance, here is something we take to be true: "humans and gorillas are mammals." If predicates have built in nature-modifiers, though, this will be false. For on that view, Gorillas are mammals-qua-gorilla, and no human is a mammal-qua-gorilla. So one peculiar entailment of this view is that either Christ does not share predicates in common with me, or I do not share them in common with other non-human animals. Conciliar Christology says that Christ shares them in common with me. Christ is "true man," just as I am. But it surely seems as if I share some in common with other 
primates, too. Is there really no zoological terminology (e.g., genera) that can be univocally predicated of both humans and another life forms? This is not insurmountable, but it is weird. One would expect Conciliar Christology to have weird entailments, but one might be excused for not expecting the entailments in the realm of species taxonomy.

In response, the $(\mathrm{P})$ theorist might qua-modify to a more general term. For instance, rather than qua-modifying to the human nature, one might modify to temporal existence. Christ, then, wouldn't be passible-qua-human; he'd be passible-qua-temporal. Then, since Christ, you, and a gorilla are all alike in existing in time, each could be a mammal-qua-temporal. In short, we can retrieve the univocal classificatory terminology by qua-modifying to a more general classificatory term.

While this is a useful strategy, it does give up on the natures playing a vital role in the response. One benefit of these four qua strategies is that one can find precedent for this sort of move in the councils, since they are rife with qua-modifications. But all those qua-modifications in the conciliar texts are to the natures. This response of modifying to some higher term foregoes that precedent, and with it, some of the motivation for qua-modifying in the first place.

I do not take the objection to the $(\mathrm{P})$ view to be as problematic as the objections to the (A) or (S) views. For one thing, the (A) and (S) views seem to me to be non-starters. (A) doesn't provide a way to avoid predicating "passible" and "impassible" to the same thing; (S) does provide a way to avoid such incompatible predications (incompatible on this response to the argument), but it does so at the cost of falsifying Conciliar Christology. I find neither of these objections to be apt of (P). (P) allows a way of denying the incompatibility without contravening Conciliar Christology.

There is one final worry I have about $(\mathrm{P})$, though. Suppose, for the sake of argument, that multiple incarnations are possible. ${ }^{16}$ Suppose that the Son could assume another human nature while retaining his current na-

16 I discuss this objection in more detail in Pawl (2016b, Chapter 6, Sections V.a. and VI.a.). See my articles on multiple incarnations (Pawl 2014b; Pawl 2015) for more analysis of the concept and its possibility. 
ture. And suppose that there were no "pre-established harmony" between the natures - they can be in different positions, doing different things, at the same time. According to Conciliar Christology, the hypostatic union makes it the case that predicates apt of the human nature of Christ are apt as well of the divine person. ${ }^{17}$ That is why we can say, along with the conciliar statements, that God died, or that God hung on the cross. If the Word assumed another human nature, predicates apt of it would also communicate to the person. But then there is a problem. The two natures could be in states that communicate incompatible predicates to the Person. One might be, say, sitting, while the other is standing. In such a case, Christ would be both sitting-qua-human and standing-qua-human. At this point another argument, of the same form as the main problem of this article, presents itself, involving only human predicates. Christ, in such a scenario, would be both sitting-qua-human and standing-qua-human. But nothing can be both sitting-qua-human and standing-qua-human. Therefore, etc.

The $(\mathrm{P})$ solution provides the means to avoid contradiction in the original Problem by qua-modifying the predicates at hand. But here the predicates are already qua-modified - they are both -qua-human, or -qua-temporal - and the problem remains. This solution, then, has difficulties, if it is possible for multiple simultaneous incarnations to occur. One should ask, then, how widespread is such a belief in multiple simultaneous incarnations? One finds it affirmed in Aquinas (ST III. q. 3 a.7), in Fr. Roch Kereszty's (2002, 382) Christology textbook, and in other places, too, that it is possible that a divine person assume more than one nature (though these thinkers, while affirming the possibility, do not affirm that any divine person did, in fact, become incarnate more than once). ${ }^{18}$

17 This is not to say that all predicates apt of the nature are apt of the person. We can truly say of the nature that it is identical with a human nature, but the divine person himself is not identical with a human nature. At this juncture, one does not need an account of which predicates transfer, since even the predicates that uncontestedly transfer are sufficient for presenting the point of this paragraph.

18 For other discussions of the possibility of multiple incarnations, see Marilyn Adams (1985; 2005; 2009, 241), J.P. Arendzen (1941, 161), Fr. Kenneth Baker (2013, 47), Sjoerd Bonting (2003), Paul Brazier (2013), William Lane Craig (2006, 63), Oliver Crisp (2008; 2009, chap. 8), Richard Cross (2005, 230-232), Paul Davies (2003), Christopher Fisher 
Consider now the final way of understanding the qua-modification. On this final view, the modified statements look like this: Christ is-according-to-his-human-nature passible; Christ is-according-to-his-divine-nature impassible. Put otherwise, Christ is-humanly passible; Christ is-divinely impassible. Here the subject is one and the same thing in both predications: it is one and the same person. This sets the (C) view apart from the (S) view, since, on the (S) view, the subjects of predication are different. And the predicate is univocally employed in both instances on this $(\mathrm{C})$ view (aside from the negation in the complement, of course), unlike the $(\mathrm{P})$ view. The difference is in the "is," then. But how can one make sense of that?

Here's a sketch of how to do it. Suppose that a necessary condition for two predications to be true in the same way, on this (C) view, is for the nature in virtue of which the characterizing itself is apt to be the same in both cases. The characterizing itself is not the subject, and it is not the predicate either. The characterizing itself is the work of the copula, and so the best way to spell out this necessary condition is by adverbially modifying the copula.

This necessary condition is not fulfilled in the Candidate predication cases. Rather, Christ is-qua-divine impassible, and Christ is-qua-human passible. The way that he is characterized by the predicate "passible" is due to his human nature, which (on this view) makes the characterization not to be in the same way as the way he is characterized by the predicate "impassible," which is aptly said of him in virtue of his divine nature. And so it is false that the Candidate predications are true in the same sense. And so the Problem is unsound, owing to a false third premise.

Consider the objections to the previous qua theories. This response avoids the objection to (A), since it provides a way to claim that the Candidate predications are true in different senses or ways. It avoids the ob-

and David Fergusson (2006), Thomas Flint (2001, 312; 2012, 192-198), Alfred Freddoso (1983; 1986), Marie George (2001), Brian Hebblethwaite (2001; 2008, 74), Fr. Roch Kereszty $(2002,382)$, Peter Kevern (2002), Eric Mascall $(1965,40-41)$, Thomas Morris $(1987,183)$, Robin Le Poidevin (2009, 183; 2011), Fr. Gerald O’Collins (2002, 19-23), Fr. Joseph Pohle (1913, 136), Fr. Michael Schmaus (1971, 241-242), Richard Sturch (1991, 43, 194-200), and Keith Ward $(1998,162)$. 
jection to (S) because one and the same thing is being characterized by the predicates, contrary to the $(\mathrm{S})$ view. It avoids the objection to $(\mathrm{P})$, the objection that either Christ shares no predicates with me, or I share no predicates with gorillas, since, for instance, "a mammal," is said univocally of me, of Christ, and of a gorilla, though, on this view, we are not characterized by that predicate in the same way. It furthermore has the benefit of both $(\mathrm{S})$ and $(\mathrm{P})$ insofar as it insulates against complementary predications being true of the same Christ in the same way at the same time.

But for all its benefits, there are problems with this theory as well. First, it requires a revision of standard logical representation. For in standard logic there is no method for symbolizing different modes of characterization. For instance, the standard mode of representation for the predication, "Christ is passible," is " $\mathrm{P}(\mathrm{c})$," where "P" is a predicate and "c" names the object of which the predicate is apt. And Christ is impassible would, it seems, be aptly represented as “ $\mathrm{P}(\mathrm{c})$," or "I(c)," where the "I" represents the predicate "impassible," and the tilde expresses negation. There is no means by which one can represent various copulas in the representational schemas standardly employed. And so this theory requires a revision of logic, or at least a revision of its representation. ${ }^{19}$

Secondly, this view is innately harder to understand than the other methods of qua-modifying. We are familiar with predications employing multiple subjects, or predications employing multiple predicates, but understanding multiple "is"s of predication is difficult. What are the relations between the "is"s? It is true that they are all different modes of predicating predicates to subjects. But the $(\mathrm{C})$ theorist cannot allow one general "is", since, were it allowed, then we could infer from "Christ is-qua-man passible" to "Christ [general] is passible." And likewise for impassibility. So we would end up with two complementary predications true at the same time with the same general copula. So this view cannot rely upon a general copula. But without a general notion of the copula, it is hard to see the relations between the different copulas in play.

19 I thank Timothy O'Connor and Sam Newlands for pushing this point in conversation. 
Finally, the same problem of multiple incarnations applies here with the (C) view as well. In a situation in which the Son becomes simultaneously incarnate in two human natures, then he could be humanly sitting and humanly standing. But those predicates are allegedly incompatible. And the only means the $(C)$ method provides for eluding that incompatibility qua-modifying the copula - has already been deployed. So the (C) method would need to be supplemented in order to resolve this difficulty.

I have not shown that these problems are insuperable. But they require the (C) theorist to say much more about how the revised logic would function, and about how to understand the copulas - more than I can say in this already-too-long article.

Finally, consider the third way of rejecting Premise 3, which I called a flat-footed response. The proponent of this view asserts that, when properly understood, the predicates I have been focusing on in this article - passible and impassible; visible and invisible, etc. - are not incompatible with one another. They may be used univocally, at the same time, in the same sense, of one and the same subject, under certain conditions. I will spell out those conditions, after I present the proper understanding of the predicates. ${ }^{20}$

This view notes that, were we to understand impassible as "unable to be causally affected" and passible as "able to be causally affected," it would be impossible for both those predicates to be apt of Christ, no matter what sort of fancy footwork one did. But there are other ways to understand the predicates. For instance, what if we understood passibility as "having a nature that is causally affectable" and impassibility as "having a nature that is not causally affectable?" In such a case, if something were to have two natures, it would at least be possible for it to fulfill both conditions. For, one nature could be causally affectable, and the other not causally affectable. In such a case, the truth conditions would be met for that one and the same thing - the thing with two natures - to be aptly called both passible and impassible. And so, on this view, Premise 3 is false. Something can be both passible and impassible.

20 To see this view worked out in much more logical detail, see Pawl (2014a).

ScientiaetFides 3(2)/2015 
This view avoids the difficulties faced by the earlier views considered. It does not require denying that "passible" and "impassible" are true of Christ at the same time, as did the first way of rejecting Premise 3. Unlike the qua solutions, it does not presuppose - in fact, it explicitly denies - that the predicates are incompatible. And so, unlike the (A) view, affirming both predicates of the divine person without modification is not problematic for it. Unlike (S), it allows both predicates to be true of one and the same person. Unlike (P), predicates such as "mammal" can be true of Jesus, you, and a gorilla in the same sense, even if modified as this theory would have them, since each of you three have a nature that meets the conditions for being aptly predicated by "mammal." Unlike (C), this theory need not modify logic or appeal to a mysterious family of copulae. The logic for this view is fairly straightforward; I've worked it out, perhaps in excess, in Pawl (2014a, sec. III).

What of multiple incarnations? This view can deal with those problems, too. Recall that the $(\mathrm{P})$ and $(\mathrm{C})$ views had problems because in a case of multiple incarnations, incompatible predicates (e.g., sitting-qua-human; standing-qua-human) were said of the same person at the same time, or had by the person in the same way (e.g., is humanly sitting; is humanly standing). But on this view, if there were multiple incarnations, one could claim that all the relevant predicates for the problem are to be understood as "passible" and "impassible" were above. For instance, to be sitting is to have a nature arranged in such-and-such a way, and to be standing is to have a nature arranged in so-and-so a way. Christ could fulfill both those conditions if he assumed two natures. And so this view, unlike the (P) and (C) views, can deal with the multiple incarnation cases.

\section{Conclusion}

In this article I have presented the Fundamental Philosophical Problem for the Christian dogma of the incarnation. I then discussed multiple responses one might give to this Problem, ruling many out as faulty, either philosophically or by being inconsistent with Conciliar Christology. My 
focus eventually settled on Premise 3, the claim that nothing can be both passible and impassible. I consider three ways of responding to Premise 3. The first denies that both predicates are apt of Christ at the same time. Conciliar Christology, I argued, is inconsistent with that claim. The second employs qua clauses to note different senses in which a thing can be passible or impassible. Each of the four ways of understanding the "qua" move have difficulties. I find the first two to have insuperable difficulties. The third, the $(\mathrm{P})$ strategy, has some jarring implications. And the final strategy, the $(C)$ strategy, is incomplete and requires revision of our standard logical system. The third and final way to respond to Premise 3 is no half-measure. It is a flat-footed denial of its truth. On this view, the allegedly incompatible predicates are not incompatible when said of the same thing, at the same time, in the same way. I have discussed the best way to understand the relevant predicates. I then showed that this final view does not fall into the same difficulties as the previous views did. ${ }^{21}$

\section{Bibliography}

Adams, Marilyn McCord. 1985. "The Metaphysics of the Incarnation in Some Fourteenth-Century Franciscans." In Essays Honoring Allan B. Wolter, edited by William A. Frank and Girard J. Etzkorn, 21-57. Franciscan Institute.

-. 2009. "Christ as God-Man, Metaphysically Construed." In Oxford Readings in Philosophical Theology, 239-63. Oxford University Press.

Adams, Marilyn McCord, and Richard Cross. 2005. "What's Metaphysically Special About Supposits? Some Medieval Variations on Aristotelian Substance.” Aristotelian Society Supplementary Volume 79 (1): 15-52.

Arendzen, J.P. 1941. Whom Do You Say-?: A Study in the Doctrine of the Incarnation. New York: Sheed and Ward.

${ }_{21}$ I thank the audiences at and participants in the First Annual LA Theology Conference (January 2013), the $8^{\text {th }}$ Annual Philosophy of Religion Conference at Baylor University (March 2013), my colloquium talk at Cardinal Stefan Wyszyński University in Warsaw, Poland (June 2014), and the brothers in my weeklong seminar on Analytic Christology at the Dominican House of Studies in Krakow, Poland (June 2014) for helpful discussion of previous versions of this paper. 
Bäck, Allan T. 1997. On Reduplication: Logical Theories of Qualification (Studien Und Texte Zur Geistesgeschichte Des Mittelalters, No 49). Brill Academic Pub.

-. 1998. "Scotus on the Consistency of the Incarnation and the Trinity." Vivarium 36 (1): 83-107.

Baker, Kenneth. 2013. Jesus Christ-True God and True Man: A Handbook on Christology for Non-Theologians. Saint Augustine's Press, Incorporated.

Bonting, Sjoerd L. 2003. “Theological Implications of Possible Extraterrestrial Life.” Zygon 38 (3): 587-602. doi:10.1111/1467-9744.00523.

Brazier, Paul. 2013. “C. S. Lewis: The Question of Multiple Incarnations.” The Heythrop Journal, 391-408. doi:10.1111/heyj.12049.

Craig, William Lane. 2006. "Flint's Radical Molinist Christology Not Radical Enough." Faith and Philosophy: Journal of the Society of Christian Philosophers 23 (1): 55-64.

Crisp, Oliver D. 2008. "Multiple Incarnations.” Reason, Faith and History: Philosophical Essays for Paul Helm, 219-38.

-. 2009. God Incarnate: Explorations in Christology. 1st ed. New York, NY, US: T\&T Clark.

Cross, Richard. 2005. The Metaphysics of the Incarnation: Thomas Aquinas to Duns Scotus. Oxford University Press, USA.

-. 2011. “The Incarnation.” In The Oxford Handbook of Philosophical Theology, edited by Thomas P. Flint and Michael Rea, 452-75. USA: Oxford University Press.

Davies, Paul. 2003. “ET and God.” The Atlantic Monthly 292 (2): 112-18.

Davis, Leo D. 1990. The First Seven Ecumenical Councils (325-787): Their History and Theology. Liturgical Press.

Davis, Stephen T. 2011. “The Metaphysics of Kenosis.” In The Metaphysics of the Incarnation, edited by Anna Marmodoro and Jonathan Hill, 114-33. Oxford University Press, USA.

Dunn, Geoffrey D. 2001. "Divine Impassibility and Christology in the Christmas Homilies of Leo the Great.” Theological Studies 62 (1): 71-85.

Evans, C. Stephen. 2006. Exploring Kenotic Christology: The Self-Emptying of God. Oxford University Press.

Fisher, Christopher L., and David Fergusson. 2006. "Karl Rahner and The Extra-Terrestrial Intelligence Question.” The Heythrop Journal 47 (2): 275-90.

Flint, Thomas P. 2001. “The Possibilities of Incarnation: Some Radical Molinist Suggestions.” Religious Studies 37 (3): 307-20.

-. 2011. "Should Concretists Part with Mereological Models of the Incarnation?" In The Metaphysics of the Incarnation, edited by Anna Marmodoro and Jonathan Hill, 67-87. Oxford University Press, USA. 
-. 2012. “Molinism and Incarnation.” In Molinism: The Contemporary Debate, edited by Ken Perszyk, 187-207. Oxford: Oxford University Press.

Forrest, Peter. 2009. “The Incarnation: A Philosophical Case for Kenosis.” In Oxford Readings in Philosophical Theology, edited by Michael C. Rea, 225-38. Oxford University Press.

Freddoso, Alfred. 1983. “Logic, Ontology and Ockham’s Christology.” The New Scholasticism 57 (3): 293-330.

-. 1986. “Human Nature, Potency and the Incarnation.” Faith and Philosophy 3 (1): 27-53.

George, Marie I. 2001. “Aquinas on Intelligent Extra-Terrestrial Life.” The Thomist 65 (2): 239-58.

Hebblethwaite, Brian. 2001. “The Impossibility of Multiple Incarnations.” Theology 104 (821): 323-34. doi:10.1177/0040571X0110400502.

-. 2008. Philosophical Theology and Christian Doctrine. John Wiley \& Sons.

Kereszty, Roch A. 2002. Jesus Christ: Fundamentals of Christology. Revised and Updated Third Edition. Staten Island, NY: Alba House.

Kevern, Peter. 2002. "Limping Principles A Reply to Brian Hebblethwaite on 'The Impossibility of Multiple Incarnations.'” Theology 105 (827): 342-47. doi:10.1177/0040571X0210500503.

Lamberz, Erich, ed. 2008. Concilium Universale Nicaenum Secundum: Concilii Actiones I-III. Vol. 3.1. Acta Conciliorum Oecumenicorum, Series Secunda. Berlin: Walter de Gruyter.

Le Poidevin, Robin. 2009. "Identity and the Composite Christ: An Incarnational Dilemma.” Religious Studies 45 (2): 167-86.

-. 2011. "Multiple Incarnations and Distributed Persons." In The Metaphysics of the Incarnation, edited by Anna Marmodoro and Jonathan Hill, 228-41. Oxford: Oxford University Press.

Mascall, Eric Lionel. 1965. Christian Theology and Natural Science: Some Questions in Their Relations. Hamden, CT: Archon Books.

Morris, Thomas V. 1987. The Logic of God Incarnate. Cornell Univ Pr.

O'Collins, Gerald. 2002. “The Incarnation: The Critical Issues.” In The Incarnation, edited by Stephen T. Davis, Daniel Kendall, and Gerald O’Collins, 1-30. Oxford: Oxford University Press.

Pawl, Timothy. 2014a. "A Solution to the Fundamental Philosophical Problem of Christology.” The Journal of Analytic Theology 2: 61-85.

-. 2014b. “Thomistic Multiple Incarnations.” The Heythrop Journal, n/a - n/a. doi:10.1111/heyj.12230. 
-. 2015. "Brian Hebblethwaite's Arguments against Multiple Incarnations.” Religious Studies FirstView (February): 1-14. doi:10.1017/S0034412514000626.

-. 2016a. “Temporary Intrinsics and Christological Predication.” In Oxford Studies in Philosophy of Religion, Volume 7, edited by Jonathan L Kvanvig. Oxford: Oxford University Press, USA.

-. 2016b. In Defense of Conciliar Christology: A Philosophical Essay. Oxford University Press.

Pohle, Joseph. 1913. Christology: A Dogmatic Treatise on the Incarnation. St. Louis: B. Herder Book Co.

Riedinger, Rudolf, ed. 1990. Concilium Universale Constantinopolitanum Tertium. Vol. 2. Acta Conciliorum Oecumenicorum, Series Secunda. Berlin: Walter de Gruyter.

Schmaus, Michael. 1971. Dogma 3: God and His Christ. First Edition. Mission, KS: Sheed and Ward.

Senor, Thomas D. 2002. “Incarnation, Timelessness, and Leibniz's Law Problems.” In God and Time: Essays on the Divine Nature. Oxford University Press.

-. 2011. "Drawing on Many Traditions: An Ecumenical Kenotic Christology.” In The Metaphysics of the Incarnation, edited by Anna Marmodoro and Jonathan Hill, 88-113. Oxford University Press, USA.

Stump, Eleonore. 2004. “Aquinas's Metaphysics of the Incarnation.” In The Incarnation, edited by Stephen T. Davis, Daniel Kendall, and Gerald O’Collins, 197-218. Oxford University Press, USA.

-. 2005. Aquinas. Routledge.

Sturch, Richard. 1991. The Word and the Christ: An Essay in Analytic Christology. Oxford; New York: Clarendon Press ; Oxford University Press.

Tanner, Norman P. 1990. Decrees of the Ecumenical Councils 2 Volume Set. Georgetown University Press.

Thompson, Thomas R. 2006. "Nineteenth-Century Kenotic Christology: The Waxing, Waning, and Weighing of a Quest for a Coherent Orthodoxy.” In Exploring Kenotic Christology, edited by C. Stephen Evans, 74-111. Oxford: Oxford University Press.

Ward, Keith. 1998. God, Faith, and the New Millennium: Christian Belief in an Age of Science. Oxford: Oneworld.

Weinandy, Thomas. 1985. Does God Change?: The Word's Becoming in the Incarnation. Still River, Mass.: St. Bede’s Publications. 